\title{
The Relationship Between Psychological Well-Being and Adversity Quotient on Fresh Graduates During Covid-19
}

\author{
Damajanti K. Dewi ${ }^{1, *}$ Priskilla N. Wijaya ${ }^{1}$, Adhita P. Puteri ${ }^{1}$ \\ ${ }^{1}$ Universitas Negeri Surabaya, Surabaya, East Java, Indonesia \\ "Corresponding author. Email: damajantikusuma@unesa.ac.id
}

\begin{abstract}
Psychological well-being can be realized by the presence of happiness in the individual. The happiness of individuals who have become fresh graduates can be achieved by having a job. The current situation which is pandemic Covid-19 situation makes it difficult to get a job, so fresh graduates need the ability to face all obstacles to realize happiness. This study aims to determine the relationship between psychological well-being and the adversity quotient of 212 fresh graduates during Covid-19. This study used the quantitative method and product-moment for the data analysis technique. The correlation coefficient obtained is 0.53 which means that there is a significant relationship between psychological well-being and the adversity quotient. Based on these results, psychological well-being affects the adversity quotient level of new graduates at the university level during Covid-19 and vice versa. The higher the individual's psychological well-being, the higher the individual's adversity quotient.
\end{abstract}

Keywords: Psychological well-being, Adversity quotient, Fresh graduates.

\section{INTRODUCTION}

The Covid-19 pandemic has an impact on every individual, especially regarding work. Some companies need to do layoffs to stay afloat during the pandemic. Based on the Ministry of National Development Planning, 3.5 million employees lost their jobs and 3.7 million were unemployed [1]. This significantly impacts fresh graduates later and needs to find work with 9.7 million other prospective employees.

Individuals who have completed their education, especially at the tertiary level referred to as fresh graduates, have the desire to be financially independent through the work they will get. The job expected by fresh graduates is certainly one that is able to meet individual social demands as graduates of a university where they are educated [2]. The role of the adversity quotient is very much needed by fresh graduates because with the ability to face and resolve the difficulties encountered, individuals will continue to persist in their life choices. The high level of adversity quotient in fresh graduates makes individuals able to face these difficulties and the goal in becoming a job will be obtained [3], [4]. Besides that, the adversity quotient effectively contributes in student's career maturity almost 23\%, which it will help the fresh graduates during Covid-19 who is a job seeker [5].

Looking for a job with the current pandemic situation, it is difficult for individuals to get a job. The existence of the adversity quotient in individuals who are looking for work will make them improve their ability to solve all obstacles in the job search process [6]. The strength of the ability to solve the difficulties faced makes individuals driven to achieve success in the business undertaken. Fresh graduates who want to have the adversity quotient ability must have several aspects, including the need for self-control, having a good interpretation of a problem, having a positive meaning to the problem, and the endurance of each individual.

Having a good adversity quotient in fresh graduates can be influenced by several factors, including competitiveness, optimism, talent, character, motivation, risk taking, intelligence, and physical and psychological health [7]. Adversity quotient itself includes 1) Selfcontrol, namely the ability to manage and control the difficulties encountered so as not to have a bad impact on individuals; 2) Origin and ownership or originownership, which is related to individual interpretation in interpreting the causes of obstacles and difficulties 
encountered; 3) Reach, namely the individual's meaning in considering certain difficulties and obstacles encountered in reaching out to other aspects of life; 4) Endurance, namely the individual's interpretation in assuming a difficulty encountered is only temporary or permanent [7].

Adversity quotient itself is very much needed by fresh graduates who are looking for work, especially to increase their life satisfaction during the Covid-19 period. The level of individual life satisfaction is closely related to psychological well-being. As we know, the life satisfaction is an essential component of the psychological well-being [8]. The existence of psychological health as a factor that affects the adversity quotient, makes individuals need psychological wellbeing to increase their ability to solve the difficulties they face. Psychological well-being is a desire and a condition in which the individual is in a state of psychological well-being. This includes not only life satisfaction and affective balance but also perceptions of the involvement of challenges in an individual's life [9].

Ryff (1989) defines psychological well-being as a condition in which an individual has fully achieved his/her psychological potential. According to Ryff, individuals who have good psychological well-being will be able to fulfill full functioning according to Rogers' view, self-actualization according to Maslow's view, Jung's concept of individuation, maturity based on Allport's concept, and achieve integration rather than despair according to Erikson's concept. Psychological well-being has six dimensions that need to be fulfilled, namely self-acceptance, positive relationships with others, autonomy, environmental mastery, life goals, and personal growth [10]-[12]. Based on this background, psychological well-being and adversity quotient influence each other. Besides that, due to Covid-19 the fresh graduates will have the double load which is seeking a job and coping during the pandemic. These facts make this research urgent to do.

\section{METHODS}

The type of research used is quantitative. Quantitative research is synonymous with numbers starting from the process of collecting, analyzing, to displaying data [13]. The independent variable in this study is psychological well-being and the dependent variable is the adversity quotient. The aims of this study are to determine the correlation between adversity quotient and psychological well-being to the participant due to Covid-19.

\subsection{Participant}

The participant in this study were 212 fresh graduates divided into 61 men and 151 women which is $15 \%$ of the study population. Total population in this research is 1.419 fresh graduates which is graduated in 2019-2020. The number of participant was determined by a purposive sampling technique which included the criteria for the participant are: 1) Graduated from the State University of Surabaya in 2019-2020; 2) The absence of work ties with other companies or agencies; 3) Individuals who were looking for work.

\subsection{Research Instruments}

The scale used in this study is the adversity quotient scale and the optimism scale. The adversity quotient scale used has been modified based on aspects of control, origin-ownership, reach, and endurance [7]. The optimism scale in this study uses a modified Revised Life Orientation Test (LOT-R) scale developed by Scheier \& Carver [14]. Those instruments were used in this research to measure the psychological well-being skill in the participant. Which is the psychological wellbeing contains six dimensions that need to be fulfilled and it can be measured using the adversity quotient and the optimism scales. Due to Covid-19, the instruments will be given to participant in an online form.

\subsection{Data Analysis}

The data analysis technique was carried out using the SPSS 25.0 application for windows. The normality test was carried out to determine the distribution of the data obtained in the study using the Kolmogorov Smirnov test for normality. The result for the adversity quotient scale is 0.26 , beside the optimism scale's result is 0.25 . Both instruments shown that the result is bigger than 0.05 and it indicates the data is normally distributed. The linearity test in the study used the ANOVA table test to determine the direction of the two variables in the study. The result of the ANOVA table test is $0.19>0.05$ and it is shown that these instruments were liniear. Hypothesis testing in this study uses Pearson's product-moment to determine whether there is a relationship between optimism and the adversity quotient.

\section{RESULTS AND DISCUSSION}

Based on the data that has been obtained from the research participant, the results of the study are in Table 1 .

The results in Table 1 explained that the psychological well-being instrument has a minimum score of 39.00 and a maximum value of 72.00 , while the optimism instrument's minimum value is 52.00 and the maximum value is 90.00 . Based on the results of the average value and the results of the standard deviation value, it shows that the two variables mean the average value is greater than the standard deviation value. It means that the data distribution in this study is homogeneous. 
Table 1. Descriptive statistics

\begin{tabular}{|l|l|l|}
\hline & $\begin{array}{l}\text { Psychological } \\
\text { Well-Being }\end{array}$ & Adversity Quotient \\
\hline Mean & 54.10 & 71.59 \\
\hline Minimum & 39.00 & 52.00 \\
\hline Maximum & 72.00 & 90.00 \\
\hline $\begin{array}{l}\text { Std. } \\
\text { Deviation }\end{array}$ & 5.49 & 7.75 \\
\hline Variance & 30.11 & 60.07 \\
\hline
\end{tabular}

Table 2. Correlation results between psychological well being and adversity quotient

\begin{tabular}{|l|l|l|l|}
\hline \multirow{4}{*}{$\begin{array}{l}\text { Psychological } \\
\text { Well-Being }\end{array}$} & $\begin{array}{l}\text { Pearson } \\
\text { Well-Being } \\
\text { Correlation }\end{array}$ & 1 & $\begin{array}{l}\text { Adversity } \\
\text { Quotient }\end{array}$ \\
\cline { 2 - 4 } & $\begin{array}{l}\text { Sig. (2- } \\
\text { tailed) }\end{array}$ & & 0.53 \\
\cline { 2 - 4 } & $\mathrm{N}$ & 212 & 0.00 \\
\hline $\begin{array}{l}\text { Adversity } \\
\text { Quotient }\end{array}$ & $\begin{array}{l}\text { Pearson } \\
\text { Correlation }\end{array}$ & 0.53 & 212 \\
\cline { 2 - 4 } & $\begin{array}{l}\text { Sig. (2- } \\
\text { tailed) }\end{array}$ & 0.00 & 1 \\
\cline { 2 - 4 } & $\mathrm{N}$ & 212 & 212 \\
\hline
\end{tabular}

Based on the table above, it can be seen that the relationship between psychological well-being and the adversity quotient has a positive relationship. It means that the adversity quotient affects the individual's psychological well-being in a linear way. The correlation test's result is 0.53 which shown the relationship between adversity quotient and psychological well-being are strong [15]. And it can be concluded there is a linear relationship between psychological well-being and adversity quotient on fresh graduates during Covid-19. It means if the individual's psychological well-being is high, it can be concluded that the individual's adversity quotient is in the same level.

Based on the results of the study, the purpose of this study was to determine the relationship between psychological well-being and the adversity quotient. The results above indicate that the relationship between the two variables is positive. So, individuals who have high psychological well-being will have a high adversity quotient also, and the relationship between these two variables is also at a strong level. The results of significant values in this study also indicate that the hypothesis in this study can be accepted, so that the two variables have a significant relationship.

The strong relationship between these two variables shows that in this pandemic situation, finding a job is quite difficult. Which is as a job seeker, the fresh graduates will need the psychological well-being and the adversity quotient in ways to cope with the stress.
Optimism is synonymous with positive expectations, where it helps individuals in dealing with problems. An optimistic individual, when facing problems will see through a positive point of view so that they are not easily stressed [14]. Adversity quotient is an individual's ability to overcome difficult times. It is necessary in helping individuals overcome the problems that arise in their lives [16].

An unfavorable situation makes an individual's adversity quotient ability influenced by factors other than psychological well-being. There are several factors that can certainly affect the level of adversity quotient in individuals that are not described in this study. According to Stoltz (2007), there are several factors that affect the adversity quotient and individuals need to pay attention to what aspects are needed to improve the adversity quotient ability. These factors are 1) individual competitiveness; 2) Optimistic attitude; 3) Talent; 4) Character; 5) Motivation; 6) Risk-taking; 7) Intelligence; 8) Health; 10) Performance; 10) Education; 11) Perseverance; 12) Repair; 13) Study; 14) Environment. This is closely related to the dimensions of psychological well-being where individuals are required to be able to change situations that are less comfortable to be comfortable for themselves. In its application, individuals need to make environmental changes, positive relationships with others, selfacceptance, and self-development [11].

Aspects related to the adversity quotient certainly make individuals more resilient in facing the difficulties they will face. These aspects have a role that encourages individuals to remain strong and have endurance. Regarding psychological well-being, the aspect of the adversity quotient is directly related to the aspect of autonomy. It makes the individual able to struggle to achieve life goals even though the surrounding environment is less supportive [6], [17]. Increasing the adversity quotient can also be increased through the aspect of environmental control of the individual and the individual's way of achieving life goals.

From this aspect, psychological well-being certainly has a relationship with the adversity quotient so that the difficulties encountered can be resolved and the life goals of fresh graduates in looking for work can be achieved. Which it related to one dimension of psychological well-being is environmental mastery [18]. This dimension helps individuals to create an environmental condition that supports their psychological well-being. While the adversity quotient is an individual's ability to overcome a problem and survive in the situation [19]. Both are related and support each other when individual face a problem.

The results of research conducted by Nindi Chadha [20] show that the adversity quotient affects an individual's psychological well-being. The ability of an individual adversity quotient that is very helpful in 
dealing with problems will affect the steps taken by individuals for problem solving and stress coping [20]. It will affect the individual's level of psychological wellbeing. The results of this study are relevant to this study, where there is a significant positive relationship between psychological well-being and the adversity quotient.

The results of this study indicate that individuals who have high psychological well-being will have a high adversity quotient as well. This is indicated by the results of data analysis which shows the correlation value between adversity quotient and psychological well-being is positive at 0.53 . So, it can be concluded that there is a significant relationship between psychological well-being and adversity quotient on fresh graduates during Covid-19. In the Covid-19 situation, individuals must have certain aspects and influencing factors to solve the difficulties they face such as stress coping strategies. Adversity quotient is important, especially for fresh graduates who are looking for work in the midst of the Covid-19 situation. Where they have a dual problem situation that Covid-19 has to deal with and how to find work. As we know, this research shows that the adversity quotient affects the psychological well-being of individuals. The higher the adversity quotient they have, the higher their psychological well-being.

\section{REFERENCES}

[1] M. Fauzia, "Akibat covid-19, jumlah pengangguran RI bertambah 3,7 juta," KOMPAS.com, 2020. .

[2] T. M. N. Rachmady and E. D. Aprilia, "Hubungan adversity quotient dengan kecemasan menghadapi dunia kerja pada freshgraduate Universitas Syiah Kuala," Psikogenesis, vol. 6, no. 1, pp. 54-60, 2018.

[3] E. D. Aprilia and Y. Khairiyah, "Optimisme menghadapi persaingan dunia kerja dan adversity quotient pada mahasiswa," SEURUNE J. Psikol. UNSYIAH, vol. 1, no. 1, pp. 18-33, 2018, doi: https://doi.org/10.24815/s-jpu.v1i1.9922.

[4] S. Drahs, L. Haywood, and A. Schiprowski, "Job search with subjective wage expectations," SSRN Electron. J., pp. 1-35, 2018, doi: $10.2139 /$ ssrn.3146764.

[5] W. Kurniawan, D. Daharnis, and Y. Karneli, "Contribution of adversity quotient, self awareness and demographic factors to student career maturity," Int. J. Res. Couns. Educ., vol. 4, no. 1, p. 70, 2020, doi: 10.24036/00261za0002.

[6] Y. Hardianto and R. B. Sucihayati, "Hubungan adversity quotient dengan career adaptability pada koas angkatan 2015 FKG ' $\mathrm{X}$ ' di RSGM,' Psibernetika, vol. 11, no. 2, pp. 79-90, 2019, doi: 10.30813/psibernetika.v11i2.1433.

[7] P. G. Stoltz, Adversity quotient: Turning obstacles into opportunities. Canada: Jon Wiley \& Sons, Inc, 1997.

[8] Y. Zhao, B. Sang, and C. Ding, "The roles of emotional intelligence and adversity quotient in life satisfaction," Curr. Psychol., 2021, doi: 10.1007/s12144-021-01398-z.

[9] W. Kusbandini and V. Suprapti, "Psychological Well Being Perempuan Dewasa Awal yang Pernah Mengalami Kekerasan Dalam Pacaran," J. Psikol. Kepribadian dan Sos., vol. 3, no. 2, pp. 80-92, 2014.

[10] C. D. Ryff, "Happiness is everything, or is it? Explorations on the meaning of psychological well-being," J. Pers. Soc. Psychol., vol. 57, no. 6, pp. 1069-1081, 1989, doi: https://doi.org/10.1037/0022-3514.57.6.1069.

[11] C. D. Ryff and L. M. Keyes, "The structure of psychological well-being revisited," J. Pers. Soc. Psychol., vol. 69, no. 4, pp. 719-727, 1995, doi: https://doi.org/10.1037/0022-3514.69.4.719.

[12] C. Ryff, "Choosing Wisely campaign builds momentum," J. Pers. Soc. Psychol., vol. 57, no. 6, pp. 1069-1081, 1989.

[13] D. M. Mertens, Research and evaluation in education and psychology, 4th ed. Washington: SAGE Publications, 2015.

[14] I. Brissette, M. F. Scheier, and C. S. Carver, "The role of optimism in social network development, coping, and psychological adjustment during a life transition," J. Pers. Soc. Psychol., vol. 82, no. 1, pp. 102-111, 2002, doi: https://doi.org/10.1037/0022-3514.82.1.102.

[15] Sugiyono, Metode Penelitian Pendidikan: Pendekatan Kuantitatif, Kualitatif, dan R\&D. Bandung: Alfa Beta, 2017.

[16] Zainudin, "Pentingnya adversity quotient dalam meraih prestasi belajar," Guru Membangun, vol. 26, no. 2, pp. 1-10, 2011.

[17] A. Rahim, "Pengaruh konsep diri dan adversity quotient terhadap kemandirian santri," Fenomena vol. 16, no. 1, pp. 61-78, 2017.

[18] S. Daretta, "Psychological well being pada korban kekerasan dalam rumah tangga," Universitas Medan Area, 2018.

[19] U. Parvathy and P. M, "Relationship between adversity quotient and academic problems among 
student teachers," IOSR J. Humanit. Soc. Sci., vol. 19, no. 11, pp. 23-26, 2014, doi: 10.9790/0837191172326

[20] N. Chadha, "Adversity quotient: Surviving rather than giving up," Psychol. Educ. J., vol. 58, no. 2, pp. 5942-5947, 2021, doi: 10.17762/pae.v58i2.3068. 